\title{
Determining and Modelling of Thermal and Rheological Properties of Cashew Apple By-Products
}

\author{
Rogéria Helen Lima Vidal, Fábia Bocayuva Carvalho, Camila Gambini Pereira \\ Laboratory of Separation Process in Foods, Department of Chemical Engineering, Federal University of Rio Grande do Norte (UFRN), \\ Natal, Brazil
}

Email address:

camila@eq.ufrn.br (C. G. Pereira)

\section{To cite this article:}

Rogéria Helen Lima Vidal, Fábia Bocayuva Carvalho, Camila Gambini Pereira. Determining and Modelling of Thermal and Rheological Properties of Cashew Apple By-Products. Engineering and Applied Sciences. Vol. 3, No. 1, 2018, pp. 29-39.

doi: $10.11648 /$ j.eas.20180301.15

Received: February 2, 2018; Accepted: February 16, 2018; Published: March 16, 2018

\begin{abstract}
This study aims to determine thermal and rheological properties of blended cashew apple juice (cajuína), nectar, and pulp. The effects of temperature on rheological properties were evaluated and the behavior was adjusted to rheological models. Comparing the thermal properties of cashew products, cajuína showed lower density, and higher values of thermal conductivity, thermal diffusivity and specific heat. Equations providing these properties in function of temperature were obtained, and presented good fits. Cajuína and cashew apple pulp were well characterized by the Ostwald-de-Waelle and Hershel-Bulkley models, respectively, while for cashew apple nectar, two behaviors were observed depending on the temperature used.
\end{abstract}

Keywords: Cashew Tree and By-products, Thermal and Rheological Properties, Rheological Modeling

\section{Introduction}

Cashew nut tree (Anacardium occidentale L.) from the Anacardiaceae family is considered one of the most economical important cultures in the Northeast of Brazil, in which Rio Grande do Norte is the state with the fourth highest production with 45.768 tons/year, in 126.198 hectares cultivated [1].

The pseudo fruit of cashew tree, the cashew apple, is rich in vitamins, tannin, mineral salts, organic acids and carbohydrate, which makes it an important food for daily consumption [2-4]. Due to the fact that different parts of the plant can be used for human consumption with highly nutritive properties, the production and consumption of this species present vast applications. The true fruit of this species is a type of almond, an oily almond greatly consumed in the internal and external markets. This is considered the main part of the plant in socio-economical terms. The cashew apple is a juicy and fibrous part of the plant that is consumed in nature as a juice or for the processing of soft drinks, alcoholic drinks, sweets, ice cream and others [5]. The production of cashew apples in the Northeast Region is estimated at about 2.5 million of tons/year, although only
$15 \%$ of the total is used industrially. The $85 \%$ of the production that is wasted presents high potential to be used for other products [6].

One of the by-products that is gaining prominence is the blended cashew apple juice called cajuína. This is a nonartificially sweetened drink that undergoes a clarification process and a specific thermal treatment in order to acquire its own organoleptic characteristics. Cajuína is a product with yellow amber color, highly appreciated due to its characteristic taste and high vitamin $\mathrm{C}$ source $[7,8]$. Due to the profile of this product there is a potential for exporting it, however the industrial processing is still recent. In parallel, for the processing in ideal industrial conditions, the knowledge of thermal and rheological properties of this fluid is essential for the control and optimization of the process.

In general, the industrial processes of cajuína, nectars and pulps use heat treatments and also cooling $[9,10]$. In these processes, the study of the influence of temperature on the rheological behavior of these products is relevant. In this way, the need for knowledge of the thermal and rheological properties of tropical fruits has been studying by some authors $[11,12]$. Generally, these properties help to assess the stability of food in relation to temperature rise and shear of 
time. However, there is a lack of data on the thermal and rheological properties for cashew apple products in literature.

Facing the needs for more knowledge of the characteristics and benefits of cashew tree by-products, this study aims to characterize and analyze the thermal and rheological properties of cajuína, nectar and pulp. Furthermore, physical characteristics $\left(\mathrm{pH}\right.$, total acidity, ${ }^{\circ}$ Brix, water activity), as well as condensed tannin and vitamin $\mathrm{C}$ contents were also determined.

\section{Materials and Methods}

\subsection{Preparation of Material}

Cajuína was obtained in a laboratory following methodology described by Silva Neto et al. [10] using the juice extracted from the appendicular fruit that was acquired in local markets, originally from producers from the Northeast of Brazil. The previous work [13], which used the same raw material, it was observed that the different lots of the raw material from the same region (Northeast of Brazil) do no influenced the results of the work. Cashew apple nectar and pulp used in this study were those from 'Maratá and Nordest fruit' brand. Cajuína and nectar were kept under refrigeration at $10^{\circ} \mathrm{C}$, at pulps $-18^{\circ} \mathrm{C}$, at the moment of analysis. The pulps were defrosted at room temperature $24^{\circ} \mathrm{C}$. Before the analysis, samples were not diluted and homogenized at room temperature $24^{\circ} \mathrm{C}$.

\subsection{Characterization of the Cashew by-Products}

Cashew by-products were characterized regarding the physical-chemical properties:

a) $p H$ : The analysis was performed using approximately 5 grams of sample. After shaking the sample for 10 minutes, the probe was inserted in the sample for the $\mathrm{pH}$ determination (MS TECNOPON, mA210, Piracicaba / SP, Brazil).

b) Total Acidity: For this analysis, it was used approximately 1 or 5 grams of sample in 10 or $50 \mathrm{~mL}$ of distilled water at room temperature. After shaking the sample for 10 minutes, that samples were titrated with $\mathrm{NaOH}$ (VETEC, lot 1009504, cod 00113708) $0.1 \mathrm{~N}$, using phenolphthalein (NEON, lot 6711) as an indicator acid, according to the methodology of IAL [14]. With the volume of $\mathrm{NaOH}$ spent in the titration, it was possible to determine the acidity of the samples, expressed as $g$ of citric acid in $100 \mathrm{~g}$ of juice, through Equation (1).

$$
\operatorname{Acid}(\%)=\frac{N V_{(\mathrm{NaOH})} 100}{m c}
$$

Where $N$ is the normality of the solution, $V_{(\mathrm{NaOH})}$ is the volume of $\mathrm{NaOH}, m$ is the mass of solution or sample and $c$ is the correction for $\mathrm{NaOH}$ solution $(0.1 \mathrm{~N}$ equivalent $c=10)$.

c) Water Activity (Aw): $5 \mathrm{~mL}$ of sample were inserted in Aqualab - Braseq (Model: S3TE, Series $n^{\circ}$ TE 8248,
Jarinu/SP, Brazil) unit, and the water activity was determined at $25 \pm 0.1^{\circ} \mathrm{C}$.

d) ${ }^{\circ}$ Brix: The analysis of total soluble solids was made in the ABBE digital refractometer (ABBE, RTA-101, Piracicaba/SP, Brazil) with the appropriate sample at $25 \pm 0.5^{\circ} \mathrm{C}$.

The cashew products were also evaluated regarding the condensed tannins and vitamin $\mathrm{C}$ contents that are the compounds most represented in this fruit.

e) Condensed tannin determination was performed through vanillin reaction using concentrated hydrochloric acid (Proquimios, lot 11/0314, 37\%) diluted in methanol (J. T. Baker - Solusob, lot K06C29, 99.96\%). An absorbance reading was performed using a spectrophotometer UV visible (Varian, Cary 50 Conc, São Paulo, Brazil) at $510 \mathrm{~nm}$ according to the method of Broadhurst and Jones [15], adapted by AgostiniCosta et al. [2].

f) Vitamin $\mathrm{C}$ analysis was performed determining the ascorbic acid content (AA) by titration with 2,6dichlorophenol indophenol (DCFI) (INLAB; Lot $834.907, \operatorname{cod} 690 ; 98 \%$ ) using $1 \%$ metaphosphoric acid (VETEC, Lot 1203237, cod 837.09) as an extraction solution, according to the methodology of Association of Official Analytical Chemists (AOAC) 967.21 adapted by Oliveira et al. [16].

The analysis of $\mathrm{pH},{ }^{\circ} \mathrm{Brix}$, total acidity and vitamin $\mathrm{C}$ for cajuína, nectar and pulp of cashew apple were performed according to the Brazilian legislation.

\subsection{Thermal Properties}

Cashew apple by-products (cajuína, nectar and pulp) were evaluated regarding the thermal properties (density, thermal conductivity, thermal diffusivity, specific heat) as described in the following.

a) Density $(\rho)$ : this property was determined using a digital densimeter (Anton Paar, model DMA 45000 M, Astralia), varying the temperature from 10 to $50^{\circ} \mathrm{C}$.

b) Thermal conductivity $(k)$ : were measured introducing the probe (SK-1) of the instrument meter KD2 (Decagon Thermal Properties Analyzer, Jarinu/SP, Brazil), in the sample. The determination was performed keeping the sample in a water bath at temperature varying from $30-60^{\circ} \mathrm{C}$. The results were expressed in $\mathrm{W} / \mathrm{m}{ }^{\circ} \mathrm{C}$.

c) Thermal diffusivity $(\alpha)$ : The determination of this property was done using a predictive equation (2) proposed for juices in function of the temperature $\left({ }^{\circ} \mathrm{C}\right)$ and ${ }^{\circ}$ Brix [17]. The results were expressed in $\mathrm{m}^{2} / \mathrm{s}$.

$$
\alpha=1.43 \times 10^{-7}+1.63 \times 10^{-10} T-2.31 \times 10^{-10} \mathrm{C}
$$

where $\mathrm{T}$ is the temperature, and $\mathrm{C}$ is the concentration in ${ }^{\circ}$ Brix.

d) Specific heat $\left(C_{p}\right)$ : From values of thermal conductivity, density and thermal diffusivity, it was possible to calculate the specific heat for the cashew products through equation 3. The results were expressed in $\mathrm{kJ} / \mathrm{kg}{ }^{\circ} \mathrm{C}$. 


$$
C_{p}=\frac{k}{\rho \times \alpha}
$$

where $C_{p}$ is the specific heat; $\mathrm{k}$ is the thermal conductivity, $\rho$ is the density, and $\alpha$ is the thermal diffusivity.

\subsection{Rheology}

The rheological behavior of cashew apple products was evaluated in a rheometer (Thermo Scientific, Haake Mars Modular Advanced Rheometer System, Germany). For the analyzes, the samples from cashew products were homogenized and were added in $12 \mathrm{~mL}$ of the rotor cup and sheared walls of coaxial cylinders that make up the rheometer.

Analyses were performed at $10-60^{\circ} \mathrm{C}$ with variation in the shear rate from 0 to $500 \mathrm{1} / \mathrm{s}$. Rheological behavior of cashew apple products was described following the models of Newton, Ostwald-de-Waelle (Potency Law) and HerschelBulkley in the temperature range studied (Equations 4-6, respectively):

$$
\begin{gathered}
\tau=\mu \gamma \\
\tau=k \gamma^{n}
\end{gathered}
$$

$$
\tau=\tau_{0}+k \gamma^{n}
$$

Where $\tau$ is the shear tension; $\mu$ is the viscosity; $\dot{\gamma}$ is the share rate; $k$ is the consistency index, $n$ is the behavior index, $\tau_{0}$ is the residual tension.

Among the different models that correlate the effect of temperature on fluid viscosity, the most used is the Arrhenius model (Equation 7).

$$
\ln \eta_{a p}=\frac{E_{a}}{R T}+B
$$

Where $\eta_{a p}$ is the apparent viscosity, $E_{a}$ is the activation energy, $\mathrm{R}$ is the universal constant of gases, $\mathrm{T}$ is the absolute temperature, and $\mathrm{B}$ is the adjustment parameter.

\section{Results and Discussion}

\subsection{Physicochemical and Thermal Properties}

Table 1 shows the properties of the cashew apple products, commercial cashew apple nectar, pulp and cajuína produced in the laboratory.

Table 1. Physicochemical properties of cashew by-products.

\begin{tabular}{llll}
\hline \multirow{2}{*}{ Properties } & Cashew apple by-products & & \\
\cline { 2 - 5 } & Cajuína & Cashew apple nectar & Cashew apple pulp \\
\hline Vitamin C (mg ascorbic acid/100 g) & $173.45 \pm 0.05$ & $51 \pm 4$ & $136 \pm 3$ \\
Condensed tannins (mg/100g) & $4.0 \pm 0,5$ & $27 \pm 2$ & $84 \pm 2$ \\
pH & $4.14 \pm 0.01$ & $3.51 \pm 0.02$ & $3.58 \pm 0.04$ \\
Total acidity (\%) & $0.390 \pm 0.001$ & $0.38 \pm 0.03$ & $0.260 \pm 0.005$ \\
Soluble solids ( ${ }^{\circ}$ Brix) & $10.8 \pm 0.0$ & $12.10 \pm 0.02$ & $11.30 \pm 0.01$ \\
Water activity (Aw) & $0.9960 \pm 0.0005$ & $0.991 \pm 0.001$ & $0.988 \pm 0.002$ \\
\hline
\end{tabular}

When comparing the properties of the products obtained, a great difference was observed in the contents of vitamin $\mathrm{C}$ and condensed tannins for the by-products evaluated. For vitamin $\mathrm{C}$, cajuína presented values $(173.43 \pm 0.05 \mathrm{mg}$ citric acid $/ 100 \mathrm{~g}$ ) superior to those observed for nectar and pulp (51 \pm 4 and $136 \pm 3 \mathrm{mg}$ citric acid $/ 100 \mathrm{~g}$, respectively). Despite this, all the values were in agreement with Brazilian legislation $[18,19]$.

Similar valor de vitamin $\mathrm{C}$ in cajuína was found by Damasceno et al. [20], in which the amount of vitamin $C$ was $179.5 \mathrm{mg}$ citric acid /100 g. It indicates that cajuína can be considered a source of vitamin $\mathrm{C}$, because, even after the heat treatment, it presented an average content of vitamin $\mathrm{C}$ around $180.25 \pm 0.05 \mathrm{mg}$ citric acid / $100 \mathrm{~mL}$, higher than that found in orange juice $(32.36 \mathrm{mg}$ citric acid / $100 \mathrm{~mL}$ ) by Danieli et al. [21]; and found in guava juice (53.61 mg citric acid / $100 \mathrm{~mL}$ ) by Souza et al. [22].

On the other hand, cajuína presented the lowest content of condensed tannins $(4,0 \pm 0,5 \mathrm{mg} / 100 \mathrm{~g})$ than nectar and pulp $(4.0 \pm 0.5 ; 27 \pm 2$ and $84 \pm 2 \mathrm{mg}$ condensed tannins $/ 100 \mathrm{~g}$, respectively). These results can be explained due to the low astringency of cajuína, which is characteristic of this product [19]. Because of this characteristic, the low tannin content, this drink has a better acceptance than natural cashew juice [2].

A comparison of condensed tannin content among nectar and pulp shows a higher difference among them. This difference is related to the amount of water added to obtain nectar, around 50\% [9], which indicates that the dilution caused by addition of water helps to reduce the concentration of tannins on this product, different from the pulp, which is an undiluted material [19]. No values of condensed tannin were found in the literature for these products.

Moreover, similar values were observed for $\mathrm{pH}$, soluble solids content and total acidity to cajuína, nectar and cashew pulp, which indicates a characteristic of products cashew apple. This can be related to factors such as maturation of pseud fruits, and different processes for the production of each product cashew apple.

The results from physicochemical analyses for cashew apple cajuína presented mean values of $\mathrm{pH}$ of $4.14 \pm 0.01$, soluble solids of $10.8 \pm 0.0^{\circ}$ Brix, total acidity of $0.390 \pm$ $0.001 \mathrm{~g}$ citric acid $/ 100 \mathrm{~g}$, and vitamin $\mathrm{C}$ of $173.43 \pm 0.05 \mathrm{mg}$ citric acid /100 g. These values showed to be in agreement with Brazilian legislation [19]. However, literature presents other values in the chemical composition cajuína [20], in $\mathrm{pH}$ 
from $4.24 \pm 0.01$ to $4.74 \pm 0.16$; in soluble solids from $10.6 \pm$ 0.1 to $12.9 \pm 0.2{ }^{\circ} \mathrm{Brix}$; in total acidity from $0.180 \pm 0.001$ to $0.397 \pm 0.006 \mathrm{~g}$ citric acid/100 g; and in vitamin $\mathrm{C}$ from 24.7 \pm 0.2 to $77.6 \pm 12.6 \mathrm{mg}$ citric acid $/ 100 \mathrm{~g}$. It indicates the lack of standardization in the manufacturing process of this product.

Cashew apple nectar presented means of $\mathrm{pH}$ at $3.51 \pm$ 0.01 . These values are close to that obtained by Lima et al. [23] for different brands of cashew apple nectar $(\mathrm{pH}=3.53 \pm$ 0.96 for brand A). These authors also found variations in $\mathrm{pH}$ $3.35 \pm 0.06$ to $3.20 \pm 0.02$ for other brands. This can be related to the different maturation states of the pseudo-fruit [24]. The values obtained (Table 1) for these properties for the cashew apple nectar $(0.38 \pm 0.03 \mathrm{~g}$ citric acid $/ 100 \mathrm{~g}$ for total acidity; $12.10 \pm 0.02{ }^{\circ}$ Brix for soluble solids, $51 \pm 4 \mathrm{mg}$ citric acid $/ 100 \mathrm{~g}$ for vitamin $\mathrm{C}$ ) are in agreement with the Brazilian legislation. However, the Brazilian legislation does not present values for $\mathrm{pH}$ parameter.

The results from physicochemical analyses for cashew apple pulp presented mean values of $\mathrm{pH}$ of $3.58 \pm 0.04$, soluble solids of $11.30 \pm 0.01{ }^{\circ} \mathrm{Brix}$, total acidity of $0.260 \pm$ $0.005 \mathrm{~g}$ citric acid $/ 100 \mathrm{~g}$, and vitamin $\mathrm{C}$ of $136 \pm 3 \mathrm{mg}$ citric acid $/ 100 \mathrm{~g}$. These values showed to be in agreement with Brazilian legislation [19]. However, Oliveira et al. [25] evaluated different brands of cashew apple pulp commercialized in Pernambuco/Brazil and observed mean values of $\mathrm{pH}$, total acidity, soluble solids ( $\left.{ }^{\circ} \mathrm{Brix}\right)$ and vitamin $\mathrm{C}$ of $4.11 \pm 0.21 ; 0.39 \mathrm{~g}$ citric acid $/ 100 \mathrm{~g} \pm 0.17 ; 9.08 \pm$
$0.77{ }^{\circ}$ Brix and $162.84 \pm 44.20 \mathrm{mg} \mathrm{AA} / 100 \mathrm{~g}$, respectively, different from determined in our study (Table 1). This can be related to the different maturation state of the pseudo-fruit used to obtain the product, or due to climatic factors such as soil type, fruit variety and amount of rain during cropping [24].

Considering the physicochemical parameters evaluated for cashew apple products, it was not found the limits set for these parameters in the Codex Alimentarius [26]. However, the description and obtaining of fruit juices and nectar followed the guidelines Codex Stan 247-2005 standard.

Regarding Table 1, all products presented water activities around 0.99. Different results were found by Pereira et al. [27] $(0.940-0.947)$ in different brands of cashew apple pulps. On the other hand, values close to that were observed in the studies conducted by Sancho et al. [28], in which value of water activities was $0.997 \pm 0.006$ for cashew apple juice when pasteurized with high pulp content. This indicates that the water activity of cashew apple products is within the range found for that type of food. However, it was not found in the literature values of water activities for cajuína and nectar.

\subsection{Thermal Properties}

Figure 1 presents the effect of temperature on the thermal properties: density, thermal conductivity, thermal diffusivity and specific heat ratio of cashew apple products.
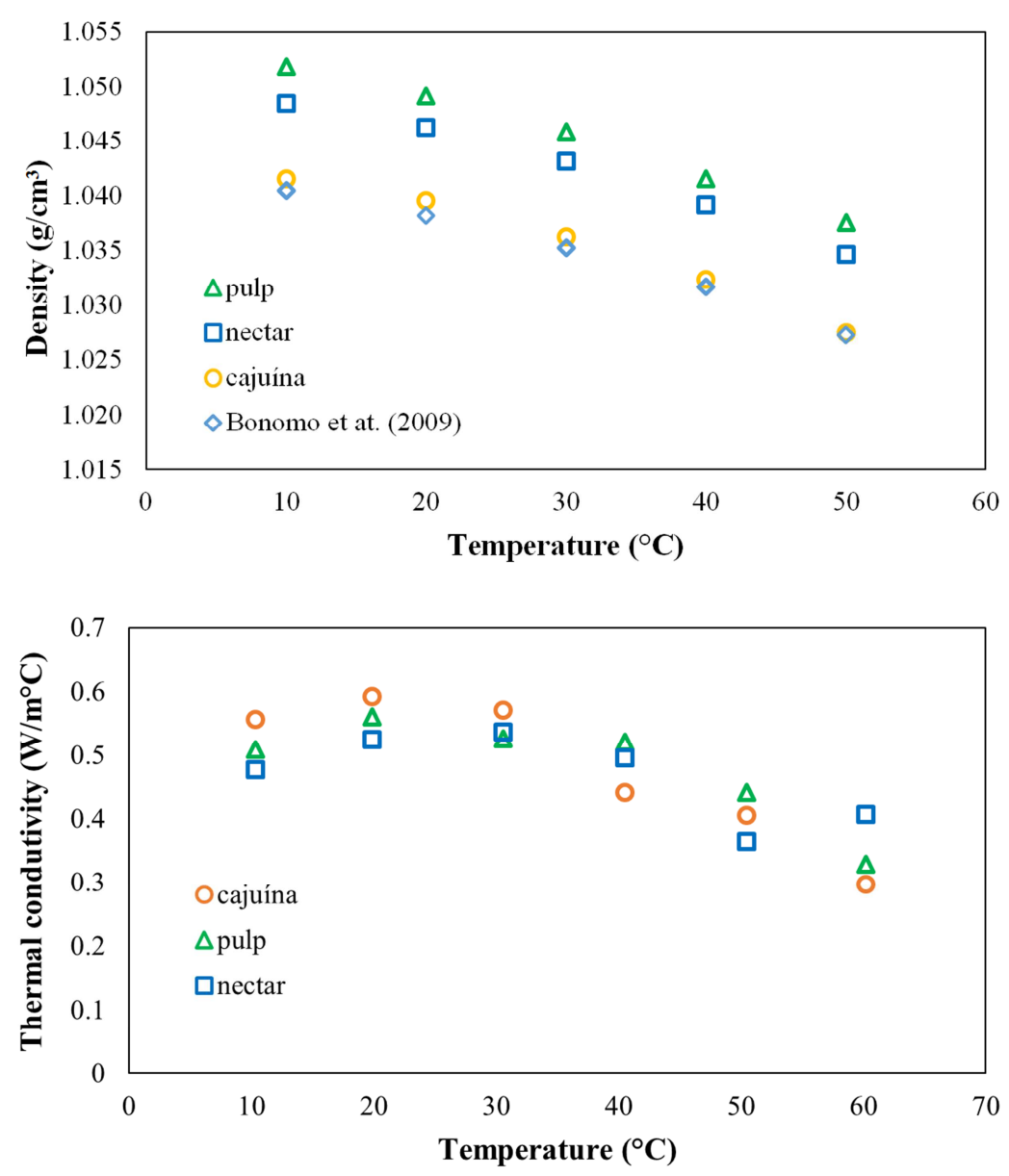

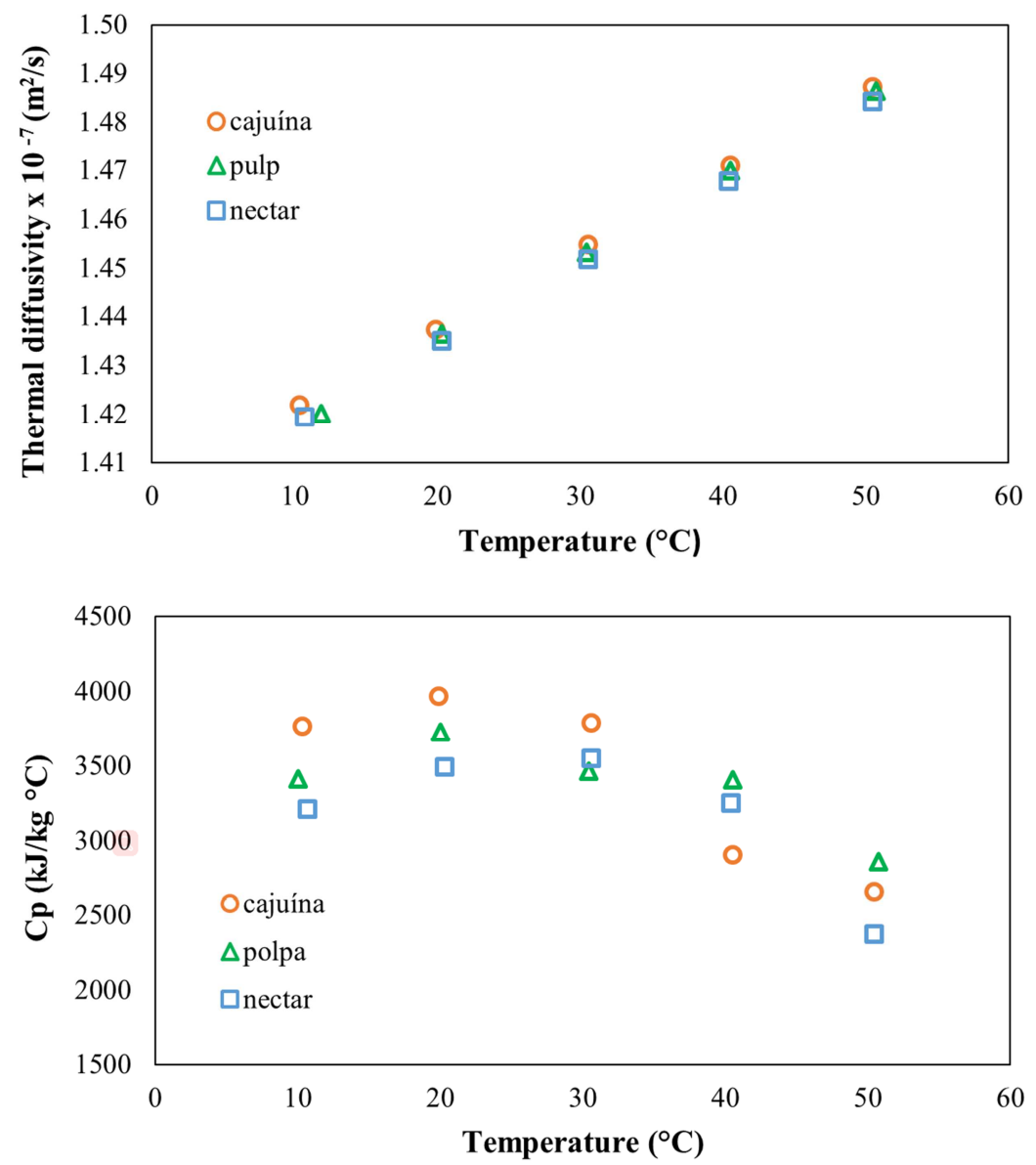

Figure 1. Effect of temperature on the thermal properties of cashew by-products: density, thermal conductivity, thermal diffusivity, specific heat.

According to Figure 1, the density of cashew apple byproducts presents a generally linear behavior as a function of temperature and that decreased with increasing temperature, in the investigated temperature range. The same behavior was observed for the cashew juice [29], which in turn presented density near to that for cajuína. Possibly this is due to the removal of particulate in suspension in cashew apple juice after filtration. Density data for nectar of cashew apple and cajuína were not found in the literature.

Considering the effect of temperature on density of cashew apple products (Figure 1), it has been verified that higher densities were observed for cashew apple pulp, followed by nectar and cashew cajuína, respectively, in the temperature 10 to $50^{\circ} \mathrm{C}$. An explanation for that is the smaller amount of water activity that favored increased density.

At given temperature $\left(30^{\circ} \mathrm{C}\right.$, for instance), the cashew apple pulp density obtained in this study $(1.0460 \pm 0.0004$ $\mathrm{g} / \mathrm{m}^{3}$ ) showed slightly lower than the value of the density obtained by Mattos and Medeiros [30], i.e., $1.0530 \pm 0.002$ $\mathrm{g} / \mathrm{m}^{3}$. This fact can also be explained by the quantity of water present in the studied cashew apple pulps.

Regarding thermal conductivity, it is possible to observe that the temperature promotes similar effect on the thermal conductivity of cajuína and cashew apple pulp, where the thermal conductivity increases from 10 to $20^{\circ} \mathrm{C}$ and decreases after $30^{\circ} \mathrm{C}$ to $50^{\circ} \mathrm{C}$. This behavior indicates that the cajuína and cashew apple pulp, at temperatures from 10 to $20^{\circ} \mathrm{C}$, leading thermal energy faster than nectar. It is also observed that cajuína has a higher thermal conductivity at temperatures from 10 to $30^{\circ} \mathrm{C}$ for cashew apple products evaluated. However, each cashew apple product had an average value of thermal conductivity as a function of temperature studied. These conductivity variations may be related to several factors, including the composition, structure, homogeneity, density, quantity of water, among others, that may affect the flow of energy through the food analyzed [31].

It's important to emphasize that values for thermal conductivity was not found in the literature for the cashew apple products evaluated in this study. The knowledge of this property is essential for process in with temperature is applied, such as thermal treatments, frozen, among others.

Considering the thermal diffusivity for cashew apple products, it is observed that the thermal diffusivity increased gradually with increasing temperature, with a linear behavior in function of temperature from 10 to $50^{\circ} \mathrm{C}$. Comparing the cashew apple products, despite these products present values close to this property, it is observed that the cajuina was the product with the highest thermal conductivity of all measured temperatures, indicating that, when these cashew apple products are subjected to the same temperature gradient, the cajuína undergo temperature changes at a greater speed than nectar and cashew apple pulp during an industrial process. However, it was not found in the literature values for thermal 
diffusivity for cajuína, cashew apple nectar and cashew apple pulp.

It can be observed that the temperature affects the specific heat of cashew apple by-products, the same behavior observed in the thermal conductivity, that is, increased with the temperature up to $20^{\circ} \mathrm{C}$ and decreased at temperatures higher than $20^{\circ} \mathrm{C}$. It is also observed that the cajuína was the food with the highest specific heat at temperatures between
10 and $30^{\circ} \mathrm{C}$. The specific heat is the quantity of heat that a food gained or lost during processing, when there are temperature changes [31]. However, it was not found in literature values for cashew apple products evaluated in this study.

From the data presented in Figure 1 it was possible to obtain the equations which correlate each thermal property in function of temperature (Table 2).

Table 2. Equations each thermal property in function of temperature* for the cashew apple by-products.

\begin{tabular}{|c|c|c|c|}
\hline Thermal property & Cashew apple by-products & Equations & $\mathbf{R}^{2}$ \\
\hline \multirow{3}{*}{ Density $\left(\mathrm{g} / \mathrm{cm}^{3}\right)$} & Cajuína & $-4.0 \times 10^{-8} \mathrm{~T}+1.0461$ & 0.9772 \\
\hline & Nectar & $-3.0 \times 10^{-8} \mathrm{~T}+1.0527$ & 0.9836 \\
\hline & Pulp & $-4.0 \times 10^{-8} \mathrm{~T}+1.0560$ & 0.9913 \\
\hline \multirow{3}{*}{ Thermal conductivity $\left(\mathrm{W} / \mathrm{m}^{\circ} \mathrm{C}\right)$} & Cajuína & $-0.0001 \mathrm{~T}^{2}+0.0044 \mathrm{~T}+0.5437$ & 0.9491 \\
\hline & Nectar & $-0.0001 \mathrm{~T}^{2}+0.0057 \mathrm{~T}+0.0469$ & 0.6682 \\
\hline & Pulp & $-0.0002 \mathrm{~T}^{2}+0.0106 \mathrm{~T}+0.4234$ & 0.9773 \\
\hline \multirow[t]{2}{*}{ Thermal diffusivity $10^{7}\left(\mathrm{~m}^{2} / \mathrm{s}\right)$} & Nectar & $0.016 \mathrm{~T}+1.402$ & 1.0000 \\
\hline & Pulp & $0.017 \mathrm{~T}+1.412$ & 0.9989 \\
\hline \multirow{3}{*}{ Specific heat $\left(\mathrm{kj} / \mathrm{kg}{ }^{\circ} \mathrm{C}\right)$} & Cajuína & $-1.1536 \mathrm{~T}^{2}+37.463 \mathrm{~T}+3579.6$ & 0.9098 \\
\hline & Nectar & $-1.9381 \mathrm{~T}^{2}+99.104 \mathrm{~T}+2342.6$ & 0.9883 \\
\hline & Pulp & $-1.0426 \mathrm{~T}^{2}+49.339 \mathrm{~T}+3056.4$ & 0.9194 \\
\hline
\end{tabular}

*Temperature in $\left({ }^{\circ} \mathrm{C}\right)$.

According to Table 2, it can be verified that the density and thermal diffusivity were the thermal properties that presented better fit with determination coefficients $\mathrm{R}^{2}>0.97$ for all cashew apple by-products with linear equations in all cases. However, the cashew apple nectar was the one with the lowest fit with $\mathrm{R}^{2}(0.6682)$ in the equation for the thermal conductivity. This indicates a behavioral shift in this thermal property at temperature of $60^{\circ} \mathrm{C}$ (Figure 1). Moreover, the equations of cashew apple pulp and cajuína presented determination coefficients between 0.9773 and 0.9491, respectively, at temperatures from 10 to $60^{\circ} \mathrm{C}$. For the specific heat polynomial equations resulted in a good fit with $\mathrm{R}^{2}$ ranging from 0.9098 and 0.9883 . It is also observed that, the thermal conductivity for cashew apple nectar in temperature between $10-50^{\circ} \mathrm{C}$, presented a good fit with $\mathrm{R}^{2}$ $(0.985)$ and equation $\left(-0.0003 \mathrm{~T}^{2}+0.0154 \mathrm{~T}+0.3451\right)$. With the exception of the thermal conductivity, for cashew apple nectar, other predictive equations of cashew apple products obtained in this study may be recommended to predict the physical properties for cajuína, the cashew apple nectar and cashew apple pulp, using the temperature value between 10 to $50^{\circ} \mathrm{C}$.

\subsection{Rheology}

Rheological behavior of cashew apple products is represented in Figure 2.

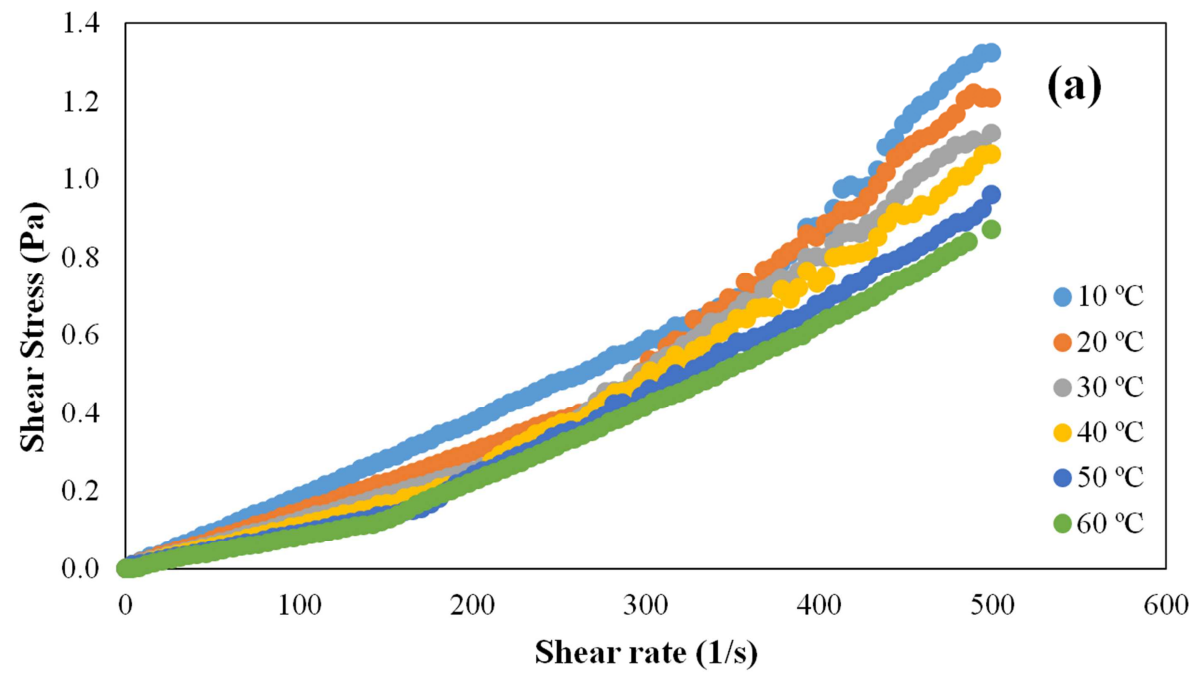



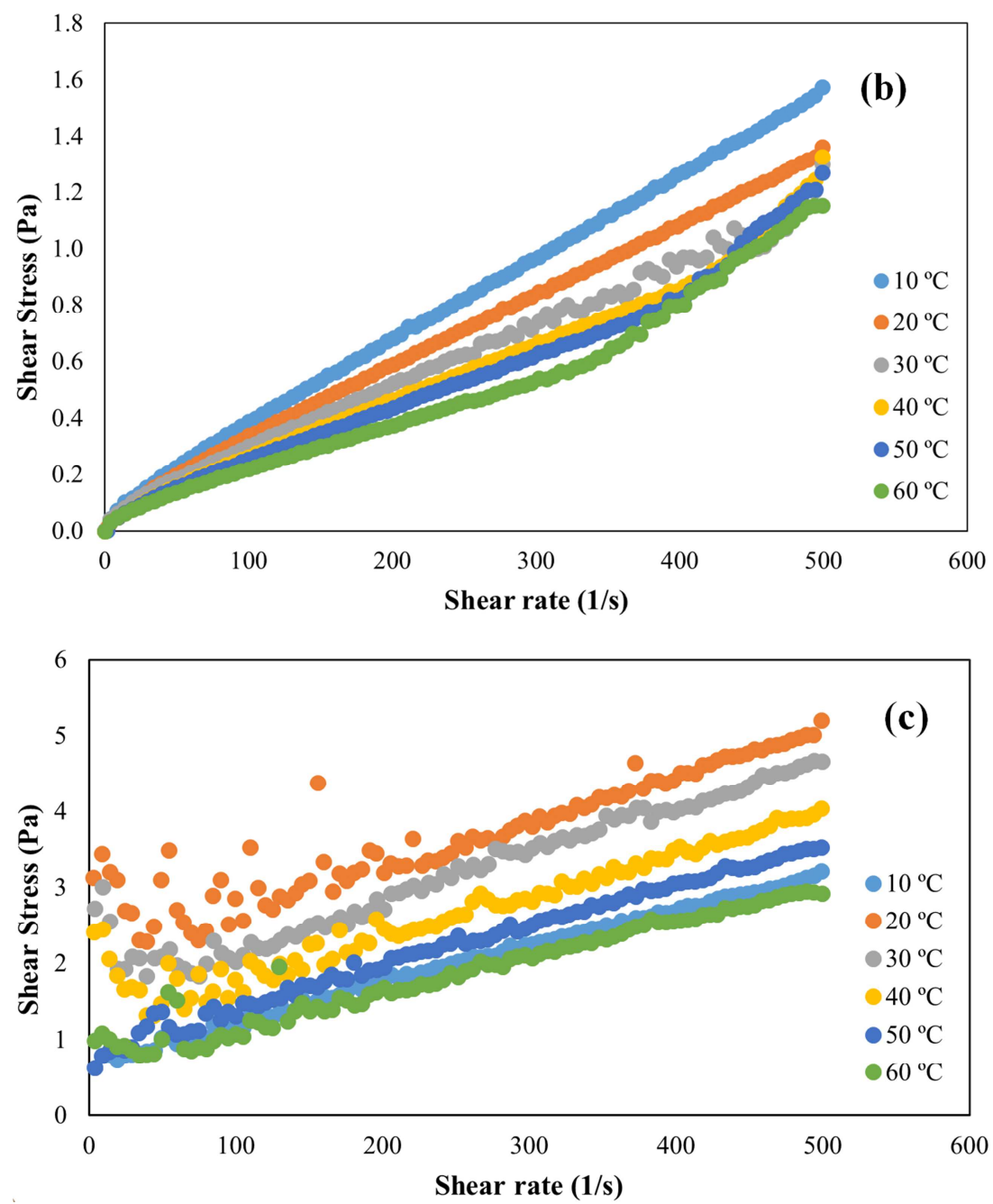

Figure 2. Rheological profile of cajuina (a), nectar (b) and chasew apple pulp (c) at different temperature.

According to Figure 2a, cajuína presented a different rheological behavior. At low shear rate $(<1001 / \mathrm{s})$ it seems to be a Newtonian fluid, however it changes to a nonNewtonian behavior increasing the shear rate. This is more evident at high temperatures. Low temperatures promoted the keeping of Newtonian behavior.

Cashew apple nectar (Figure 2b) is the product which profile was closer to fitting Newton's Law, while cashew apple pulp (Figure 2c) is the product that presented a clear non-Newtonian profile.

In contrast to the other products, cashew apple pulp presented differentiated behavior, not only when rheological profiles were considered, but also due to the tendency observed when the temperature was increased (the shear stress decreased), excepted at $10^{\circ} \mathrm{C}$. This behavior was also observed for mangaba (Hancornia speciosa) and graviola (Annona muricata) pulps [32]. In the case of the cashew apple pulp, this inversion may be attributed to the presence of interacting with starch suspended material, including the characteristic that pulp fiber. According to Silva et al. [33], a very viscous characteristic can be provided by the fibers present in cashew apple pulp. Salgado et al. [34] found a content of $2.3 \pm 0.2 \%$ of dietary fiber in the cashew apple pulp, due to the presence of cellulose and lignin, being the latter responsible for the firmness and rigidity to the fiber assembly. In the study presented here, the fiber content in cashew apple pulp was 3\% (indicated by the product's manufacturer: Nordest Fruit) and other products (cajuína and cashew apple nectar) free of fibers: for cajuína, the fibers were removed during the clarification process, and nectar, the information amount of zero fiber was provided by the product's manufacturer.

The flow curves of each product at different temperatures were adjusted to the rheological models (Equations 4-6) and Table 3 present the values for the parameters obtained in the model adjusted for cajuína, cashew apple nectar, and pulp, respectively. 
Table 3. Adjustment parameters of different models for the rheological behavior of cashew apple nectar, pulp and cajuina, respectively, at different temperatures.

\begin{tabular}{|c|c|c|c|c|c|c|c|}
\hline \multirow[t]{2}{*}{ Cashew apple by-products /Models } & & \multicolumn{2}{|c|}{ Temperature $\left({ }^{\circ} \mathbf{C}\right)$} & \multirow[b]{2}{*}{30} & \multirow[b]{2}{*}{40} & \multirow[b]{2}{*}{50} & \multirow[b]{2}{*}{60} \\
\hline & & 10 & 20 & & & & \\
\hline \multicolumn{8}{|l|}{ Cajuína } \\
\hline \multirow[t]{2}{*}{ Newtonian } & $\mu$ & 0.0022 & 0.0021 & 0.0019 & 0.0018 & 0.0016 & 0.0015 \\
\hline & $\mathrm{R}^{2}$ & 0.9721 & 0.9627 & 0.9628 & 0.9678 & 0.9706 & 0.9721 \\
\hline \multirow[t]{3}{*}{ Ostwald-de-Waelle } & $\mathrm{k}$ & 0.0002 & 0.0001 & 0.0001 & 0.0001 & 0.0001 & 0.0001 \\
\hline & $\mathrm{n}$ & 1.3927 & 1.5644 & 1.5704 & 1.5253 & 1.4928 & 1.4782 \\
\hline & $\mathrm{R}^{2}$ & 0.9909 & 0.9960 & 0.9979 & 0.9988 & 0.9991 & 0.9995 \\
\hline \multirow[t]{4}{*}{ Herschel-Bulkley } & $\tau_{\mathrm{o}}$ & 0.09 & 0.06 & 0.04 & 0.03 & 0.01 & 0.008 \\
\hline & $\mathrm{k}$ & 0.0000 & 0.0000 & 0.0000 & 0.0000 & 0.0000 & 0.0000 \\
\hline & $\mathrm{n}$ & 1.7131 & 1.7851 & 1.7290 & 1.6210 & 1.5416 & 1.5150 \\
\hline & $\mathrm{R}^{2}$ & 0.9945 & 0.9981 & 0.9990 & 0.9992 & 0.9992 & 0.9996 \\
\hline \multicolumn{8}{|l|}{ Nectar } \\
\hline \multirow[t]{2}{*}{ Newtonian } & $\mu$ & 0.0032 & 0.0028 & 0,0024 & 0.0023 & 0.0022 & 0.0020 \\
\hline & $\mathrm{R}^{2}$ & 0.9955 & 0.9949 & 0,9904 & 0.9911 & 0.9876 & 0.9809 \\
\hline \multirow[t]{3}{*}{ Ostwald-de-Waelle } & $\mathrm{k}$ & 0.0065 & 0,0059 & 0,0056 & 0.0025 & 0.0017 & 0.0007 \\
\hline & $\mathrm{n}$ & 0.8806 & 0.8723 & 0.8585 & 0.9845 & 1.0445 & 1.1835 \\
\hline & $\mathrm{R}^{2}$ & 0.9994 & 0.9995 & 0.9961 & 0.9911 & 0.9880 & 0.9862 \\
\hline \multirow[t]{4}{*}{ Herschel-Bulkley } & $\tau_{0}$ & 0.06 & 0.05 & 0.06 & 0.09 & 0.11 & 0.07 \\
\hline & $\mathrm{k}$ & 0.0039 & 0.0036 & 0.0027 & 0.0005 & 0.0002 & 0.0002 \\
\hline & $\mathrm{n}$ & 0.9583 & 0.9456 & 0.9674 & 1.2190 & 1.3829 & 1.3561 \\
\hline & $\mathrm{R}^{2}$ & 0.9999 & 0.9999 & 0.9970 & 0.9939 & 0.9929 & 0.9918 \\
\hline \multicolumn{8}{|l|}{ Pulp } \\
\hline \multirow[t]{3}{*}{ Ostwald-de-Waelle } & $\mathrm{k}$ & 0.0910 & 1.0492 & 0.4557 & 0.3446 & 0.1203 & 0.1054 \\
\hline & $\mathrm{n}$ & 0.5650 & 0.2350 & 0.3607 & 0.3791 & 0.5374 & 0.5293 \\
\hline & $\mathrm{R}^{2}$ & 0.9889 & 0.8118 & 0.8865 & 0.8793 & 0.9860 & 0.9502 \\
\hline \multirow[t]{4}{*}{ Herschel-Bulkley } & $\tau_{\mathrm{o}}$ & 0.6018 & 2.7275 & 1.9806 & 1.6509 & 0.7343 & 0.8458 \\
\hline & $\mathrm{k}$ & 0.0104 & 0.0001 & 0.0007 & 0.0004 & 0.0114 & 0.0018 \\
\hline & $\mathrm{n}$ & 0.8871 & 1.5810 & 1.3368 & 1.4010 & 0.8862 & 1.1420 \\
\hline & $\mathrm{R}^{2}$ & 0.9984 & 0.9488 & 0.9766 & 0.9718 & 0.9966 & 0.9810 \\
\hline
\end{tabular}

Cajuína, even after the process of clarification and thermal treatment during manufacturing, presented characteristic behavior of fruit juices with values of $\mathrm{R}^{2}>0.99$ for the Ostwald-de-Waelle and Hershel-Bulkley models. Despite the high $\mathrm{R}^{2}$ values $(>0.99)$ observed for the Hershel-Bulkley model, this model is not applicable for cajuína due to a null consistency index, which indicates that this property has no effect in the model and therefore the model cannot be used. Thus, the model of Ostwald-de-Waelle was indicated for this product. This fluid showed a dilatant behavior $(\mathrm{n}>1)$ evaluated at all temperatures, indicating that at these temperatures there is a higher shear stress due to the difficulty of disposing, as shown in Figure 2a.

In relation to cashew apple nectar, this product presented Newtonian behavior for temperatures between 10 and $40^{\circ} \mathrm{C}$ $\left(\mathrm{R}^{2} \approx 0.99\right)$. The increase in temperature changed the rheological behavior from high share rates $(>3001 / \mathrm{s})$. The fluid deviates from the Newtonian behavior and fits better into the Hershel-Bulkley model $\left(\mathrm{R}^{2} \approx 0.99\right)$.

For cashew apple pulp, the Hershel-Bulkley model presented the best result $\left(\mathrm{R}^{2} \approx 0.98\right)$. This behavior was also observed for other types of pulps such as açaí, jabuticaba (Plinia cauliflora) and siriguela (Spondias purpurea L.) pulps
[36-38]. A higher dispersion was observed at the starting point of the share rate (up to $\pm 100 \mathrm{1} / \mathrm{s}$ ) followed by rapid homogeneous behavior by the fluid. This dispersion is probably due to the suspended material, including fibers, characteristic of cashew apple pulp.

For cashew apple pulp, considering the effect of temperature on the parameters of the models, the increase in temperature leaded to a decrease in consistency index $(\mathrm{k})$ and an increase in the behavior index (n) in the model of Ostwald-de-Waelle, except at $10{ }^{\circ} \mathrm{C}$. For the Hershel-Bulkley model, the increase in temperature promoted a decrease in residual tension and behavior index, with no tendency observed for the consistency index in the range studied (10 and $60^{\circ} \mathrm{C}$ ).

For cashew apple nectar, the increase in temperature decreased the viscosity in the Newtonian model, and the same effect was observed for the consistency index in the model of Ostwald-de-Waelle and Hershel-Bulkley. This behavior was also observed for cajuína.

The analysis of the effect of temperature by the Arrhenius model corroborates to the facts previously observed. Figure 3 present the apparent viscosity analysis against the deformation rate applied. 

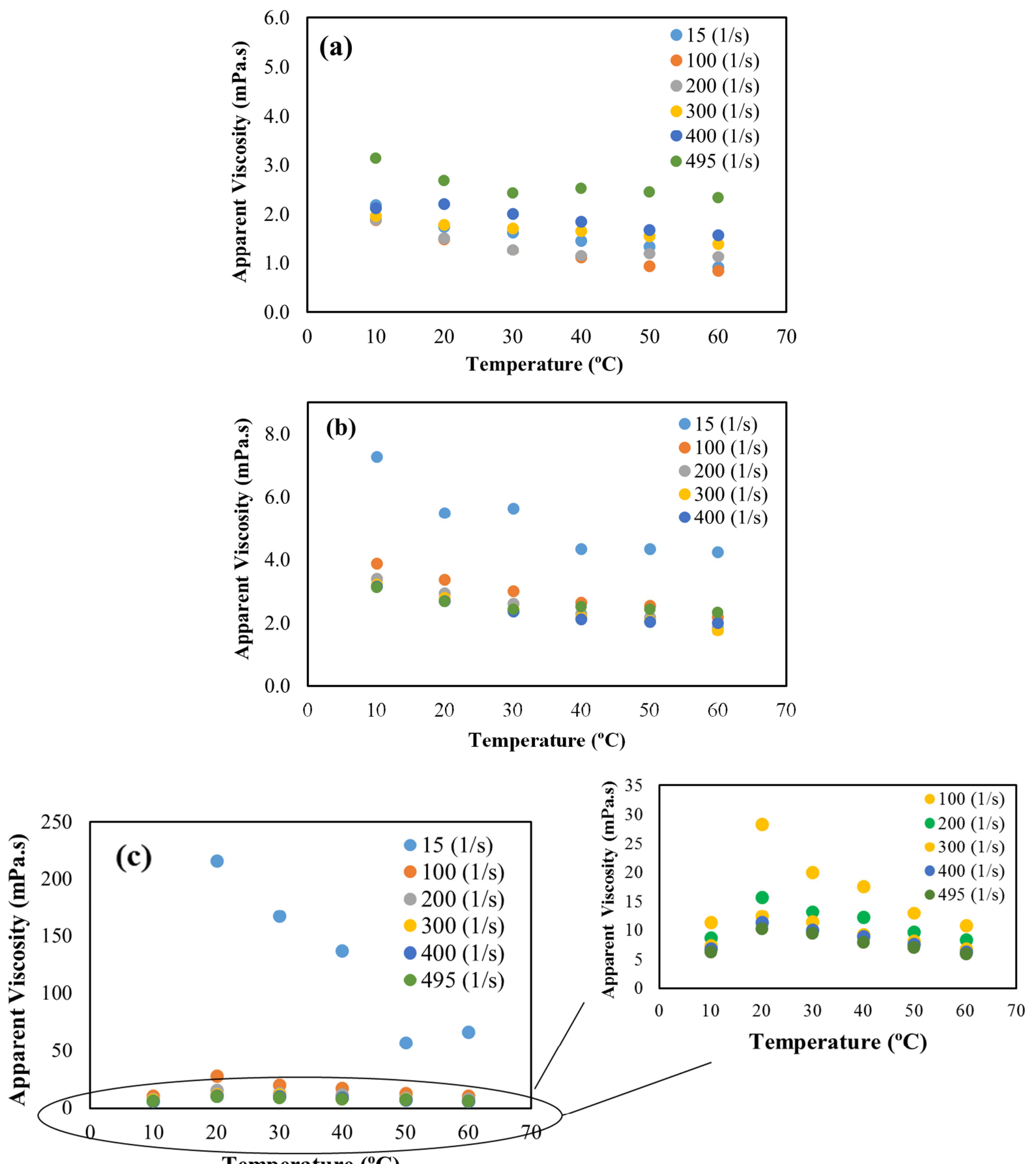

Temperature $\left({ }^{\circ} \mathrm{C}\right)$

Figure 3. Effect of temperature on apparent viscosity of cajuina (a), nectar (b) and cashew apple pulp (c) at different shear rates.

Cajuína (Figure 3a) behaved stably, presenting a slight decrease in apparent viscosity as the temperature increased. For cashew apple nectar (Figure 3b), similar behavior to that observed for the pulp was obtained when low share rates were applied $(151 / \mathrm{s})$, but at a lower intensity. For higher share rates, the increase in temperature tends to slightly decrease apparent viscosity. For cashew apple pulp (Figure $3 \mathrm{c}$ ) due to the great dispersion observed at the beginning of share rate (up to $\pm 1001 / \mathrm{s}$, as presented in Figure 2c), it is observed that pulp behavior at $15 \mathrm{1} / \mathrm{s}$ is distant from those observed in other share rates. At $15 \mathrm{1} / \mathrm{s}$ rate, the increase in temperature sharply decreases the apparent viscosity. At other share rates, the increase in temperature also decreases apparent viscosity, at a lower intensity. A differentiated behavior of the pulp at $10^{\circ} \mathrm{C}$ as shown in Figure $2 \mathrm{c}$ was still observed in Figure 3c. This behavior could be initially attributed to the soluble solid content of cashew apple pulp. However, cashew apple pulp showed ${ }^{\circ}$ Brix with a small difference relative to the other cashew products (Table 1) which did not show such behavior. As discussed earlier, this behavior may be due to interactions between starch and suspended material, including fibers, this pulp.

In general, the magnitude level of apparent viscosity of these products was as follows: cashew apple pulp $>$ nectar $>$ 
cajuína.

In relation the adjustment parameters in the Arrhenius model, different activation energy values were obtained for the cashew apple by-products; being the highest activation energy observed for cashew apple pulp $(1538.7 \mathrm{~J} / \mathrm{mol})$ when compared with cajuína $(8.4436 \mathrm{~J} / \mathrm{mol})$ and cashew apple nectar $\left(12.2670 \mathrm{~J} / \mathrm{mol}\right.$ ) at $4001 / \mathrm{s}$ (with $\mathrm{B}=-2.4746, \mathrm{R}^{2}=$ $0.9742, \mathrm{~B}=0.0265, \mathrm{R}^{2}=0.9833 ; \mathrm{B}=0.5004, \mathrm{R}^{2}=0.9853$ to cashew apple pulp, cajuína and nectar e respectively). The activation energy indicates how much of the temperature influences the rheological parameters of the fluid This is confirm the results previously presented in which a higher effect of temperature was observed, followed by nectar and cajuína, that presented a lower temperature effect on rheological behavior.

\section{Conclusion}

In this study, the cashew apple by-products of cajuína, nectar and pulp were characterized regarding their physicochemical, thermal and rheological properties. Among the physicochemical properties, special attention should be given to cajuína which presented higher vitamin $\mathrm{C}$ and lower condensed tannin contents. Cashew apple by-products presented in accordance with to those recommended by the Brazilian legislation. Thermal properties, the cajuína showed the lowest density. In general, all products showed good fits of predictive equations for each evaluated thermal property. Rheological analyses of the products indicated that cajuína and cashew apple pulp are well characterized by the Ostwald-de-Waelle models and Hershel-Bulkley ( $\mathrm{n}>1$ ), respectively. Cashew apple nectar presented Newtonian behavior for the temperatures between $10-40^{\circ} \mathrm{C}$ and, at higher temperatures, the Ostwald-de-Waelle model adjusted better to the fluid behavior. The results were coherent with those from literature regarding fruit pulps and similar products, and the values of these properties were consistent. The great importance of this work opens new possibilities to the food industry and provides a base for the development of industrial products from tropical fruits with new exotic flavors.

\section{Acknowledgements}

The authors are grateful to $\mathrm{CNPq}$ for its financial support and the Post-Graduation Program in Chemical Engineering (PPGEQ) by encouraging and supporting the research.

\section{References}

[1] IBGE, 2012. Levantamento Sistemático da Produção Agrícola: Pesquisa Mensal de Previsão e Acompanhamento das Safras Agrícolas no Ano Civil, Rio de Janeiro, 25:1-88. ftp://ftp.ibge.gov.br/Producao_Agricola/Levantamento_Sistem atico_da_Producao_Agricola_[mensal]/Fasciculo/2012/1spa_2 01202.pdf. Accessed 25 January 2015.

[2] Agostini-Costa T. S., A. Lima, and M. V. Lima. (2003).
Tannin in cashew apple: vanillin versus butanol acid assay. Química Nova, 26:763-765.

[3] Santos R. P., A. A. X. Santiago, C. A. A. Gadelha, J. B. Cajazeiras, B. S. Cavada, J. L. Martins, T. M. Oliveira, G. A. Bezerra, R. P. Santos, and V. N. Freire. (2007). Production and characterization of the cashew (Anacardium occidentale L.) peduncle bagasse ashes. Journal of Food Engineering, 79:1432-1437.

[4] Michodjehoun-Mestres L, J. M. Souquet, H. Fulcrand, E. Meudec, M. Reynes, and J. M. Bailout. (2009). Characterization of highly polymerized from skin and flesh of four cashew apple (Anacardium occidentale L.) genotypes. Food Chemistry, 114:989-995.

[5] Cruz N. J. T., M. V. Silva, and R. A. Moraes Filho. (2007). Consumo dos principais produtos derivados do caju e potencialidade dos produtos alternativos do caju na cidade de Maceió-Alagoas/Brazil. XLV Congresso da Sociedade Brasileira de Economia, Administração e Sociologia Rural "Conhecimentos para Agricultura do Futuro". Londrina/PR, Brazil. http://www.sober.org.br/palestra/6/874.pdf Accessed 20 june 2015 .

[6] Holanda J. S., J. F. Torres, M. T. Oliveira, L. Ferreira Filho, and A. C. Holanda. (2010). Da carne de caju à carne de cordeiro. Boletim de Pesquisa e Desenvolvimento. $\mathrm{N}^{\circ} 35$ ISSN 01012975, EMPARN - Empresa de Pesquisa Agropecuária do RN, Brazil, pp: 42. http://adcon.rn.gov.br/ACERVO/EMPARN/DOC/DOC000000 000000565.PDF. Accessed 10 September 2015.

[7] Campos D. C. P., A. S. Santos, D. B. Wolkoff, V. M. Matta, L. M. C Cabral, and S. Couri, (2002). Cashew apple juice stabilization by microfiltration. Desalination, 148:61-65.

[8] Damasceno L. F., F. A. N. Fernandes, M. M. A. Magalhães, and E. S. Brito. (2008). Non-enzymatic browning in clarified cashew apple juice during thermal treatment: Kinetics and process control. Food Chemistry, 106:172-179.

[9] Paiva F. F. A., D. S. Garrutti, and R. M. Silva Neto. (2000). Aproveitamento industrial do caju. Documento 38. Embrapa Agroindústria Tropical, Fortaleza/CE, Brazil, ISSN: 01035797, Pages: 88.

[10] Silva Neto R. M., F. A. P. Abreu, and F. F. A. Paiva. (2009). Processamento do pedúnculo de caju: Cajuína. Documento 123. Embrapa Agroindústria Tropical. Fortaleza/CE, Brazil, ISSN: 1677-1915, Pages: 38.

[11] Moura S. C. S. R., S. P. M. Germer, D. C. P. Jardim, and M. S. Sadahlra. (1998). Thermophysical properties of tropical fruit juices. Brazilian Journal of Food Technology., 1:70-76.

[12] Silva F. C., D. H. P. Guimarães, and C. A. Gasparetto, (2005). Rheology of acerola juice: effects of concentration and temperature. Food Science Technology, 25:121-126.

[13] Vidal, R. H. L., and C. G. Pereira. (2015). Ion Exchange Resin Applied to Obtain Clarified Cashew Juice. Separation Science and Technology, 50: 2737-2746.

[14] IAL, 2008. Instituto Adolfo Lutz. Métodos físico-químicos para alimentos. $4^{\mathrm{a}}$ Ed.; São Paulo/SP, Brazil.

[15] Broadhurst R. B., and W. T. Jones. (1978). Analysis of condensed tannins using acidified vanillin. Journal Science Food Agriculture, 29:788-794. 
[16] Oliveira R. G., H. T. Godoy, and M. Prado. (2010). Optimization of a colorimetric method to determine ascorbic acids in fruit jelly. Food Science Technology, 30:244-249.

[17] Cabral R. A. F., C. E. Orrego-Alzate, A. L. Gabas, and J. Telis-Romero, 2007. Rheological and thermophysical properties of blackberry juice. Food Science Technology, 27:589-596

[18] Brazil, (2003). Ministério da Agricultura, Pecuária e do Abastecimento. Regulamento Técnico para Fixação dos Padrões de Identidade e Qualidade para Néctares de frutas. Instrução Normativa $N^{\circ} 12,04$ September 2003.

[19] Brazil, (2000). Ministério da Agricultura, Pecuária e do Abastecimento. Regulamento Técnico para Fixação dos Padrões de Identidade e Qualidade para polpa de frutas e suco de caju clarificado ou cajuína. Instrução Normativa $N^{\circ}$ 01, 07 January 2000.

[20] Damasceno L. F. (2007). Estudo das interações polifenolproteína e das reações de escurecimento não-enzimático para o processamento de cajuína. $78 \mathrm{f}$. Master Thesis. UFRN, DEQ, Natal, Brazil.

[21] Danieli F., L. R. L. G. Costa, L. C Silva, A. S. S. Hara, and A. A. Silva. (2009). Determination of vitamin C in sample orange juice in natura and commercials samples of orange juice pasteurized and bottled in Tetra Pak packages, Journal Health Science Institution., 27:361-365.

[22] Souza L. M., L. P. Barreto, T. M. Moraes, D. F. N. Silva, C. G. S. Oliveira, and G. C. Silva. (2010). Determinação de vitamina $\mathrm{C}$ comparando dois métodos volumétricos em sucos de acerola (Malpighia emarginata), goiaba (Psidium guajava) e caju (Anacardium occidentale). X Jornada de Ensino, Pesquisa e Extensão (JEPEX), UFRPE, Recife/PE, Brazil.

[23] Lima F. A., M. A. Raiol, O. G. Bino, C. I. C Barbosa, C. E. Souza, and A. Santos Silva. (2015). Estudo físico-químico e quimiométrico de néctar de caju industrializados. In: 55 Congresso Brasileiro de Química. Recursos Renováveis: Inovação e Tecnologia. Goiânia/GO, Brazil.

[24] Silva Lima E., E. G. Silva, J. M. Moita Neto, and G. C. Moita. (2007). Vitamin C degradation in industrialized cashew juice (Anacardium occidentale L.) and in cajuína. Química Nova, 30:1143-1146.

[25] Oliveira M. E. B., M. S. R. Bastos, T. Feitosa, M. A. A. C. Branco, and M. G. G. Silva. (1999). Physical chemical parameters evaluation of acerola, yellow mombin and cashew apple frozen pulps. Food Science Technology, 19 (3), ISSN: $1678-457 \mathrm{X}$

[26] Codex Stan 247-2005. Codex general standard for fruit juices and nectars. Codex Stan, pp1-19. file:///C:/Users/Usu\%C3\%A1rio/Downloads/CXS_247e.pdf. Accessed in 20 june 2016.
[27] Pereira J. M. A. T. K., K. A. M. Oliveira, N. F. F. Soares, M. P. J. C. Gonçalves, C. L. O. Pinto, and E. A. F. Fontes. (2006). Avaliação da qualidade físico-química, microbiológica e microscópica de polpas de frutas congeladas comercializadas na cidade de Viçosa-MG. Alimentos \& Nutrition, 17:437-442.

[28] Sancho S. O., G. A. Maia, R. W. Figueiredo, S. Rodrigues, and P. H. M. Sousa. (2007). Physicochemical changes in cashew apple (Anacardium occidentale L.) Juice processing. Food Science Technology, 27:878-882.

[29] Bonomo R. C. F., R. C. I. Fontan, T. S. de Souza, C. M. Veloso, M. F. T. Reis, and S. S. Castro. (2009). Thermophysical properties of cashew juice at different concentrations and temperatures. Revista Brasileira de Produtos Agroindustriais, 11:35-42.

[30] Mattos J. S., and B. J. T. Medeiros. (2008). Density of tropical fruits pulp database and e experimental determination. Revista Brasileira de Engenharia e Biossistemas, 2:109-118.

[31] Meireles M. A. A., and C. G. Pereira (2013). Fundamentos de Engenharia de Alimentos. Vol. 6, Atheneu. (Coleção Ciência, Tecnologia, Engenharia de Alimentos e Nutrição - CCTEAN), São Paulo/SP, Brazil, pp: 815.

[32] Pitombeira G., and C. G. Pereira. (2011). Comportamento reológico das polpas de frutas tropicais congeladas. In: IX Simpósio Latino Americano de Ciência de Alimentos, Campinas/SP, Brazil.

[33] Varela MSS, Pitombeira CGR, Silva ACN, Pereira CG. (2017) Determination and Modeling of Thermophysical and Transport Properties of Tropical Pulps. European Journal of Biophysics. 5 (5): 79-88.

[34] Silva L. M. R., G. A. Maia, R. W. Figueiredo, A. M. Ramos, D. K. R. Holanda, and N. M. Vieira. (2012). Ajuste dos parâmetros reológicos de polpas de acerola, caju e manga em função da temperatura: modelos de Ostwald-de-Waelle, Herschel-Bulkley e Casson. Revista Brasileira de Produtos Agroindustriais, 14:37-49.

[35] Salgado S. M., N. B. Guerra, and A. B. de Melo Filho. (1999). Frozen fruit pulps: effects of the processing on dietary fiber contents. Revista de Nutrição, 12:303-308.

[36] Carneiro F. R. B. D. (2000). Conservação de polpa de açaí por métodos combinados. Master thesis, FEA, UNICAMP, Campinas, Brazil.

[37] Sato A. C., and R. L. Cunha. (2007). Influence of temperature on the rheological behavior of jaboticaba pulp. Food Science Technology, 27:890-896.

[38] Augusto, P. E. D., M. Cristianini, and A. Ibarz (2012). Effect of temperature on dynamic and steady-state shear rheological properties of siriguela (Spondias purpurea L.) pulp. Journal Food Engineering, 108:283-289. 